\title{
RERATA INTENSITAS WARNA TERPISAH UNTUK IDENTIFIKASI DAGING KAMBING, DAGING BABI, DAGING CELENG, DAN DAGING ANJING
}

\author{
Afri Yudamson $^{1 *}$, Titin Yulianti ${ }^{2}$, FX Arinto Setyawan ${ }^{3}$, Sri Ratna Sulistiyanti ${ }^{4}$ \\ Jurusan Teknik Elektro, Fakultas Teknik Universitas Lampung \\ Jl. Prof. Soemantri Brodjonegoro No. 1 Gedong Meneng Bandar Lampung, 35145 \\ Penulis Korespodensi : afri.yudamson@eng.unila.ac.id
}

\begin{abstract}
Abstrak
Paper ini memaparkan hasil penelitian untuk mengidentifikasi beberapa jenis daging menggunakan metode rerata intensitas warna terpisah. Sampel yang digunakan dalam penelitian ini adalah daging Anjing, daging Babi, daging Celeng, dan daging Kambing karena dengan kasat mata, beberapa jenis daging tersebut tampak serupa. Sampel-sampel tersebut ditangkap menggunakan kamera android. Kemudian setiap citra yang dihasilkan, disegmentasi untuk memisahkan citra daging dari latar belakangnya. Kemudian dihitung nilai persentase dari Red, Green, dan Blue. Hasil penelitian menunjukkan bahwa rentang nilai persentase Red dari 50,78\% sampai 53,87\% dapat menjadi ciri daging Anjing, rentang nilai persentase Green dari $29,11 \%$ sampai $31,43 \%$ dapat menjadi ciri daging Babi dan daging Celeng, dan rentang nilai persentase Blue dari 25,33\% sampai 28,22\% dapat menjadi ciri daging Kambing.
\end{abstract}

Kata kunci: daging serupa, segmentasi citra, rerata intensitas warna terpisah, karakterisasi citra

\begin{abstract}
[Title: Separate Color Intensity Average to Identify Lambs, Porks, Boar meats, and Dog meats] This paper reports our research about identifying some kinds of meats using separate color intensity average. Samples used in this research are Dog meat, Pork, Boar meat, and Lambs because these types of meat seen similar in plain view. Those sample images were acquired by the android camera. Then each image was segmented to separate from the background. After that, the values of Red, Green, and Blue percentages were calculated. The results show that Red percentage range of $50.78 \%$ to $53.87 \%$ can be the characteristic of Dog meats, Green percentage range of $29.11 \%$ to $31.43 \%$ can be the characteristic of Pork and Boar meats, and Blue percentage range of $25.33 \%$ to $28.22 \%$ can be the characteristic of Lambs.
\end{abstract}

Keywords: similar meat, segmented image, separate color intensity average, image characterization

\section{Pendahuluan}

Kesegaran daging dapat diklasifikasikan dengan menggunakan nilai-nilai intensitas RGB dan HIS. Nilai mean dan histogram yang dihitung secara matematis dapat mengklasifikasi kesegaran daging berdasarkan warna (Chiana dkk, 2014). Nilai intensitas komponen RGB pada citra daging dapat digunakan untuk mengenali beberapa jenis daging. Daging yang digunakan sebagai sampel adalah daging kambing, babi, dan anjing. Hal ini karena daging ini terlihat mirip dengan mata telanjang. Daging ini memiliki warna dan serat yang mirip jika tidak ada lemak.

\section{Dasar Teori}

Citra beberapa jenis daging, secara kasat mata akan tampat serupa. Kiswanto telah dapat mengidentifikasi Citra untuk Mengidentifikasi Jenis Daging Sapi dengan Menggunakan Transformasi Wavelet Haar (Kiswanto, 2012). Selanjutnya, Julia
Rosmaya Riasari telah meneliti tentang perbedaan karakteristik daging sapi dengan daging babi (Riasari dan Rosmaya, 2014). Lalu, Elvia Budianita telah meneliti tentang Implementasi Pengolahan Citra dan Klasifikasi K-Nearest Neighbour untuk Membangun Aplikasi Pembeda Daging Sapi dan Babi (Budianita dkk, 2015). Lalu, Dedy Yuristiawan telah melakukan penelitian tentang Aplikasi Pendeteksi Tingkat Kesegaran Daging Sapi Lokal Menggunakan Ekstraksi Fitur Warna dengan Pendekatan Statistika (Yuristiawan, 2015).

\section{Citra RGB}

Citra yang direpresentasikan dalam model warna RGB terdiri dari tiga buah komponen citra. Masing-masing citra Red, Green, dan Blues merupakan citra 8-bit. Dengan demikian, masing-masing piksel warna RGB dikatakan memiliki lebar 24-bits (Gonzalez dkk, 2008). 
Rerata intensitas warna terpisah merupakan metode untuk mendapatkan nilai persentase komponen R, G, dan B. Nilai-nilai tersebut dapat dihasilkan dengan menggunakan persamaan berikut:

$$
\begin{aligned}
\% R & =\frac{\bar{R}}{\bar{R}+\bar{G}+\bar{B}} \\
\% G & =\frac{\bar{G}}{\bar{R}+\bar{G}+\bar{B}} \\
\% B & =\frac{\bar{B}}{\bar{R}+\bar{G}+\bar{B}}
\end{aligned}
$$

$\% R=$ Persentase komponen Red

$\% G=$ Persentase komponen Green

$\% B=$ Persentase komponen Blue

$\bar{R}=$ Nilai rerata intensitas komponen Red

$\bar{G}=$ Nilai rerata intensitas komponen Green

$\bar{B}=$ Nilai rerata intensitas komponen Blue

\section{Bahan dan Metode}

Sampel diletakkan di atas piring kemudian dilakukan penangkapan citra. Citra RGB ditangkap dengan menggunakan kamera digital untuk masingmasing sampel. Kemudian seluruh sampel disimpan ke penyimpanan PC untuk diolah.

Untuk memisahkan citra daging dari latar belakangnya dilakukan segmentasi citra. Citra sebelumnya dipisah per matriks R, G, dan B. Kemudian diambil selisih antara komponen $\mathrm{R}$ dan $\mathrm{G}$ sebagai dasar segmentasi. Untuk smoothing dalam segmentasi, citra tersebut difilter dengan median filtering. Selanjutnya segmentasi dilakukan dengan tresholding citra. Di bawah nilai threshold, nilai intensitas akan menjadi nol dan yang lain akan sama dengan citra aslinya. Gambar 1 menunjukkan salah satu citra daging kambing yang telah tersegmentasi sehingga latar belakang dibuat menjadi nol.

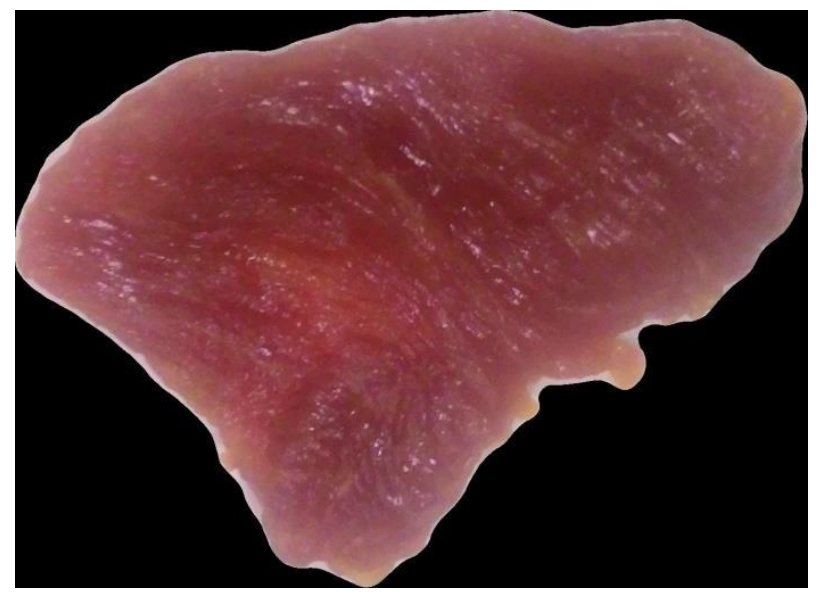

Gambar 1. Contoh citra daging kambing tersegmentasi

Proses utama dimulai dengan menghitung nilai rerata intensitas masing-masing komponen citra $R, G$, dan B. lalu rerata intensitas warna terpisah dihitung dengan menggunakan persamaan (1), (2), dan (3).

\section{Hasil Penelitian}

Sampel yang digunakan dalam penelitian ini adalah daging kambing, anjing, dan babi. Masingmasing jenis daging dipotong dengan cara membujur dan melintang. Jumlah sampel daging dipotong membujur sebanyak 5 sampel, begitu pula untuk daging yang dipotong melintang. Dengan demikian, tiga jenis daging yang digunakan akan menghasilkan sampel sebanyak 30 buah.

Gambar 1, 2, dan 3 menunjukkan persentase nilai rerata intensitas citra Red, Green, dan Blue dari keseluruhan sampel. Sumbu horizontal digunakan sebagai nama sample. B berarti sampel yang dipotong membujur sedangkan L berarti sampel yang dipotong melintang. Garis Biru digunakan untuk Daging Anjing, Garis Merah digunakan untuk Daging Babi, Garis Hijau digunakan untuk Daging Celeng, dan Garis Ungu digunakan untuk Daging Kambing. Kemudian Tabel 1 menunjukkan nilai Minimum, Maximum, dan Ratarata persentase Red, Green, dan Blue dari setiap jenis daging.

Dari Gambar 2 dapat dilihat bahwa citra daging anjing memiliki nilai persentase Red tertinggi yaitu pada rentang $50,78 \%$ sampai $53,87 \%$. Nilai untuk daging anjing untuk keseluruhan sampel tidak beririsan dengan nilai pada sampel daging lainnya. Dengan demikian rentang persentase Red tersebut dapat menjadi ciri untuk daging anjing.

Dari Gambar 3 dapat dilihat bahwa citra daging babi dan celeng memiliki nilai persentase Green tertinggi yaitu citra daging babi pada rentang $29,11 \%$ sampai $31,42 \%$ sedangkan citra daging celeng pada rentang $29,86 \%$ sampai $31,43 \%$. Nilai untuk daging babi dan celeng untuk keseluruhan sampel tidak beririsan dengan nilai pada sampel daging lainnya. Dengan demikian, masing-masing rentang persentase Green tersebut dapat menjadi ciri untuk daging babi dan celeng.

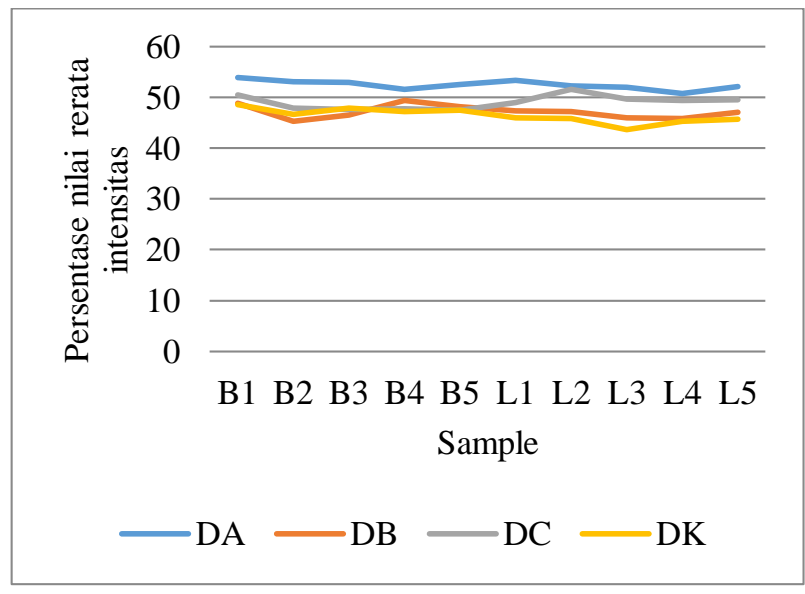

Gambar 2. Grafik Persentase Citra Red 


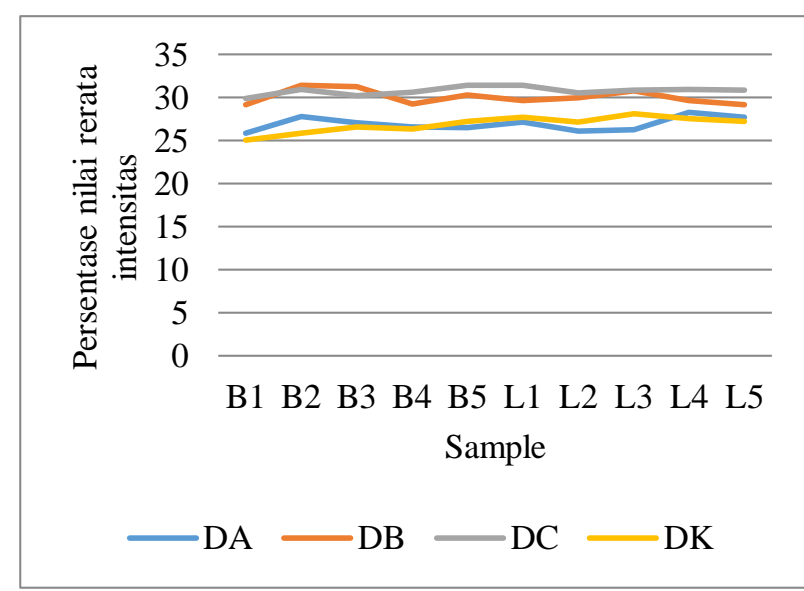

Gambar 3. Grafik Persentase Citra Green

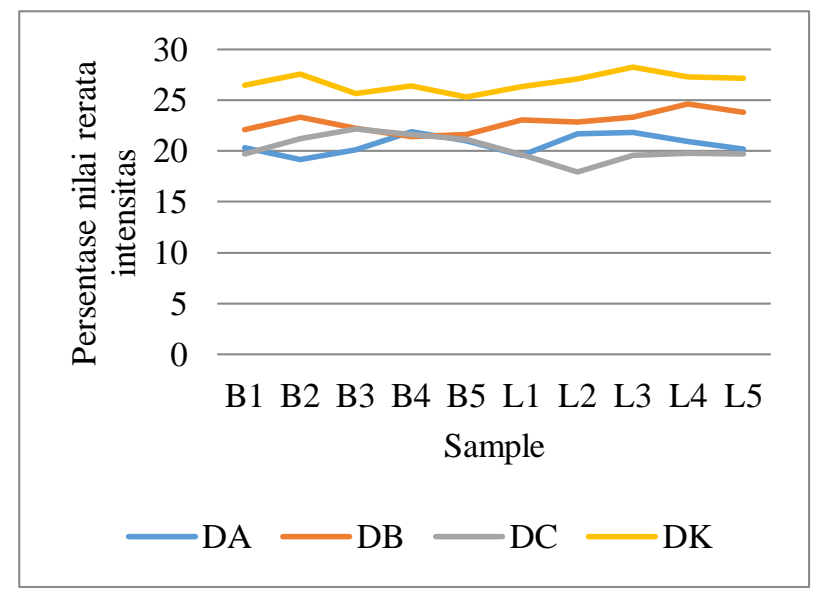

Gambar 4. Grafik Persentase Citra Blue

Dari Gambar 4 dapat dilihat bahwa citra daging kambing memiliki nilai persentase Blue tertinggi yaitu pada rentang $25,33 \%$ sampai $28,22 \%$. Nilai untuk daging kambing untuk keseluruhan sampel tidak beririsan dengan nilai pada sampel daging lainnya. Dengan demikian rentang persentase Blue tersebut dapat menjadi ciri untuk daging kambing.

Tabel 1. Persentase Citra Red, Green, and Blue

\begin{tabular}{lllll}
\hline Daging & & \%R & \%G & \%B \\
\hline Daging & Min & 50.78 & 25.80 & 19.16 \\
Anjing & Max & 53.88 & 28.29 & 21.90 \\
& Rata-rata & 52.43 & 26.91 & 20.66 \\
Daging & Min & 45.22 & 29.12 & 21.39 \\
Babi & Max & 49.35 & 31.43 & 24.65 \\
& Rata-rata & 47.12 & 30.04 & 22.84 \\
Daging & Min & 47.40 & 29.86 & 17.90 \\
Celeng & Max & 51.60 & 31.43 & 22.17 \\
& Rata-rata & 49.00 & 30.76 & 20.24 \\
Daging & Min & 43.65 & 25.05 & 25.34 \\
Kambing & Max & 48.48 & 28.13 & 28.22 \\
& Rata-rata & 46.40 & 26.87 & 26.74 \\
\hline
\end{tabular}

\section{Kesimpulan Dan Saran}

Kesimpulan yang dapat diambil dari hasil penelitian ini antara lain:

1. Persentase komponen Red pada rentang 50,78\% sampai $53,87 \%$ dapat menjadi ciri untuk daging Anjing.

2. Persentase komponen Green pada rentang $29,11 \%$ sampai $31,43 \%$ dapat menjadi ciri untuk daging Babi dan daging Celeng.

3. Persentase komponen Blue pada rentang 25,33\% sampai $28,22 \%$ dapat menjadi ciri untuk daging Kambing.

Penulis menyarankan agar penelitian ini dapat diteruskan untuk mendapatkan karakteristik daging dari bentuk seratnya.

\section{Ucapa Terima Kasih}

Terima kasih kepada LPPM UNILA, yang telah memberikan dukungan keuangan melalui DIPA PNBP FT.

\section{Daftar Pustaka}

V. Nai Chiana, F. S. A. Saada, M.F.Ibrahima, S. Sudina, A. Zakaria, A.Y.M. Shakaff (2014). Meat Color Recognition and Classification Based on Color using NIR/VIS Camera. 8th MUCET 2014, Date: 10-11 November 2014, Melaka, Malaysia

Kiswanto (2012). Identifikasi Citra untuk Mengidentifikasi Jenis Daging Sapi dengan Menggunakan Transformasi Wavelet Haar. Tesis Magister Sistem Informasi Universitas Diponegoro Semarang.

Riasari, Julia Rosmaya (2014). Perbedaan Karakteristik Daging Sapi dan Daging Babi. Institut Pertanian Bogor.

Budianita, Elvia, dkk (2015). Implementasi Pengolahan Citra dan Klasifikasi K-Nearest Neighbour Untuk Membangun Aplikasi Pembeda Daging Sapi dan Babi. Jurnal Sains, Teknologi dan Industri, Vol. 12, No. 2, Juni 2015, pp.242 - 247 ISSN 1693-2390 print/ISSN 2407-0939 online.

Yuristiawan, Dedy (2015). Aplikasi Pendeteksi Tingkat Kesegaran Daging Sapi Lokal Menggunakan Ekstraksi Fitur Warna dengan Pendekatan Statistika. Riptek Vol. 9, No. 1, Tahun 2015, Hal. 9 - 16.

Gonzalez, R.C., Richard E. Woods (2008). Digital Image Processing, Prentice-Hall, Inc., Upper Saddle River, New Jersey. 